\title{
Testy słowne dostępne i wykorzystywane w Polsce w audiometrii mowy - rys historyczny
}

\section{Speech tests available and used in Poland as part of speech audiometry - historical outline}

\author{
Edyta Piłka
}

Instytut Fizjologii i Patologii Słuchu, Światowe Centrum Słuchu, Zakład Audiologii Eksperymentalnej, Warszawa/Kajetany

Adres autora: Edyta Piłka, Światowe Centrum Słuchu, Zakład Audiologii Eksperymentalnej, ul. Mokra 17, Kajetany, 05-830 Nadarzyn, e-mail: e.pilka@ifps.org.pl

\section{Streszczenie}

W określonym czasie i określonej wspólnocie ludzkiej mowa pełni funkcję komunikacyjną. Metody badawcze oparte na sygnale mowy mają szczególne znaczenie w procedurze dopasowania urządzeń wspomagających słyszenie oraz prowadzeniu treningu słuchowego. W audiometrii słownej wykorzystywane są specjalnie skonstruowane testy. Ich wybór uwarunkowany jest tym, czy istnieje potrzeba określenia ubytku słuchu w sposób ilościowy, czy też celem diagnozy jest typ i miejsce uszkodzenia słuchu. W języku polskim do celów diagnostycznych najczęściej wykorzystywane są testy liczbowe i listy słów jednosylabowych.

Słowa kluczowe: testy słowne • listy artykulacyjne • listy lingwistyczne • audiometria słowna

\begin{abstract}
In a specific time and specific human community speech fulfills a communicative function. Research methods based on a speech signal are particularly important in the procedure of fitting of devices assisting in hearing and conducting auditory training. Speech audiometry tests use specially constructed texts, selected in each case based on requirements: whether test is performed for quantitative evaluation of hearing loss, or is it focused on the type and location of hearing dysfunction. In the Polish language most popular diagnostic tests are numerical tests and monosyllable words lists.
\end{abstract}

Key words: speech tests • articulation lists • linguistic lists • speech audiometry

\section{Wprowadzenie}

Mowa jest systemem elementów głosowych, które zostały ukształtowane w toku biologicznej i społecznej ewolucji człowieka [1]. Układ słuchowy, dzięki temu że sygnał mowy pełni rolę komunikacyjną i zarazem jest jednym z najbardziej naturalnych dla niego dźwięków, posiada zdolność nie tylko przyjmowania treści informacyjnych zawartych w tym sygnale, lecz także rozumienia go w procesach ośrodkowego przetwarzania [2].

Metody badawcze wykorzystujące mowę pozwalają ocenić wydolność słuchową i ograniczenia układu słuchowego, uwzględniając przy tym zjawiska zachodzące na poziomie akustycznym, neurologicznym, a także lingwistycznym $[3,4]$. Ma to szczególne znaczenie w procedurze dopasowywania urządzeń wspomagających słyszenie i prowadzeniu treningu słuchowego, a także w diagnostyce zaburzeń ośrodkowego przetwarzania sygnału mowy [5-7].
W audiometrii słownej wykorzystywane są specjalnie skonstruowane testy lingwistyczne (słowne, artykulacyjne), utworzone ze słów reprezentatywnych dla całego zasobu wyrazowego danego języka, zrozumiałych dla wszystkich, bez względu na wykształcenie, poziom inteligencji, wiek, zawód czy płeć. W celu uzyskania obiektywności testu opracowywany materiał słowny, zawarty w listach artykulacyjnych, poddawany jest różnym zabiegom językoznawczym [3]. Może podlegać zrównoważeniom akustycznym, semantycznym, gramatycznym, energetycznym, fonematycznym, fonetycznym, strukturalnym i dynamicznym. Zrównoważenie testu słownego pod względem akustycznym polega na tworzeniu list w taki sposób, aby w każdej z nich znalazły się słowa należące do określonych grup akustyczno-fonetycznych. Zrównoważenie semantyczne polega na tym, że wyrazy umieszczane we wszystkich listach powinny być wybierane spośród najczęściej występujących w języku polskim z wykorzystaniem słowników frekwencyjnych. Natomiast zrównoważenie gramatyczne wiąże się z użyciem określonej części mowy w danych 
testach artykulacyjnych, np. rzeczowniki w listach dyskryminacyjnych. Zrównoważenie energetyczne polega na użyciu jednostek słownych zbudowanych $\mathrm{z}$ sylab równo akcentowanych. Fonematyczne zrównoważenie uwzględnia częstość występowania fonemów na listach słownych, tak aby była jak najbardziej zbliżona do częstości ich występowania $\mathrm{w}$ danym języku. Z kolei zrównoważenie fonetyczne polega na tym, że wyrazy tworzące listy lingwistyczne zawierają poszczególne głoski w takim stosunku procentowym, w jakim występują w języku potocznym. Strukturalne zrównoważenie występuje wówczas, gdy użyte struktury samogłoskowo-spółgłoskowe są najczęstsze dla wyrazów budujących listę słowną. Dynamiczne zrównoważenie odnosi się do nagrania list na jednakowym poziomie ciśnienia akustycznego [4].

Wybór testu lingwistycznego wykorzystywanego w audiometrii słownej uwarunkowany jest tym, czy istnieje potrzeba określenia ubytku słuchu w sposób ilościowy ${ }^{1}$, czy też celem diagnozy jest typ i miejsce uszkodzenia słuchu. Wyróżnić można listy logatomowe, które nie niosą informacji semantycznej, listy mową ciągłą, czyli zdania logiczne o naturalnej intonacji, a także listy spondejowe złożone $\mathrm{z}$ wyrazów dwusylabowych, w których na każdą sylabę przypada identyczny akcent. Kolejne to listy liczb dwucyfrowych, listy mieszane, tworzone $\mathrm{z}$ wyrazów wielosylabowych oraz listy wyrazów jednosylabowych, wykorzystywane do ustalania ubytków dyskryminacji mowy. W języku polskim najczęściej do celów diagnostycznych wykorzystywane są testy liczbowe i testy słowne składające się z list wyrazów jednosylabowych [4].

Do interpretacji wyników z poszczególnych list artykulacyjnych wykorzystywane są krzywe normatywne, które ilustrują procent rozpoznawania mowy w funkcji poziomu sygnału mowy. Wyznaczone są na podstawie badań na określonej liczbie osób i różnią się w zależności od testu [4].

Pierwsze próby związane z pomiarem oceny rozumienia mowy ludzkiej, poprzez powtarzanie sylab, zostały przeprowadzone w Stanach Zjednoczonych (USA) przez Cambella w roku 1910. Miały one bezpośredni związek z praktyczną oceną jakości łączy telefonicznych [8]. Jednakże pierwsze diagnostyczne testy słowne (Western Electric 4C), wykorzystywane w USA do określenia progu słyszenia, zostały opracowane dopiero w roku 1947 przez Hudginsa, Hawkinsa, Karlina i Stevensa w Bell Telephone Laboratories [9]. Rok później w Harvard Psychoacustic Laboratory powstały testy PAL PB-50 Egana i Hudginsona [10]. Obejmowały one 20 list złożonych z 50 wyrazów każda. Posiadały jedynie zrównoważenie fonetyczne. W późniejszych latach Hirsch zmienił materiał lingwistyczny w tych testach i zrównoważył go również semantycznie. Listy te do dziś są jednymi $\mathrm{z}$ najpopularniejszych testów amerykańskich znanych pod nazwą CID W 22 (Central Institute for Deaf $W$-22).

\section{Cel pracy}

Testy słowne opracowywane dla języka polskiego były tworzone i modyfikowane $\mathrm{w}$ wielu pracowniach audiologicznych w Polsce, często przy współpracy z ośrodkami z zagranicy. Celem pracy było przedstawienie opisanych w dostępnej literaturze przedmiotu testów słownych wykorzystywanych w codziennej praktyce audiologicznej. W tabeli 1 zaprezentowano chronologiczny wykaz testów słownych stosowanych w audiometrii mowy.

\section{Polskie testy słowne wykorzystywane w audiometrii mowy}

Pierwsze polskie testy słowne pojawiły się w 1953 roku, czyli 5 lat po pierwszych amerykańskich listach słownych. Zostały opracowane w Klinice Otolaryngologicznej Akademii Medycznej i Pracowni Fonetyki Państwowej Akademii Nauk w Poznaniu [11]. Aleksander Zakrzewski wraz z zespołem utworzyli 10 list artykulacyjnych składających się z 50 wyrazów jednosylabowych. Autorzy testu założyli, że dłuższe listy mogłyby wprowadzić niepożądany czynnik zmęczenia u osoby badanej. Przerwa pomiędzy prezentowanymi wyrazami wynosiła 5 sekund. Podczas prac związanych $\mathrm{z}$ układaniem list brano pod uwagę to, aby jednostki słowne wykorzystane w teście miały charakter uniwersalny, czyli były zrozumiałe dla każdego. W tym celu $\mathrm{w}$ pierwszym etapie prac z 1000 polskich wyrazów jednosylabowych wykluczono słowa trudne do zrozumienia, szczególnie wyrazy obce takie jak pens, Fin czy elf. Wyeliminowano także wyrazy podobnie brzmiące - róg, rów, ród. W niektórych przypadkach, na podstawie wyników prób wstępnych, decydowano o eliminacji jednego wyrazu z dwóch brzmiących podobnie. Zachowywano ten, który podczas prób był zawsze rozumiany np. z zestawu grad i grab zostawiono grab. Kolejnym krokiem było wykluczenie słów trudnych, takich jak np. zżąć. Przyjęto zasadę, zgodną z tendencjami wymowy języka polskiego, ubezdźwięcznienia spółgłosek dźwięcznych w wygłosie. Każdy z użytych ostatecznie w liście wyrazów był sprawdzany przez co najmniej 25 osób na różnych poziomach natężeń dźwięku. W ten sposób z zasobu 1000 słów zostało 650. Z 500 ułożono 10 list zawierających po 50 słów, natomiast $\mathrm{z}$ pozostałych stworzono rezerwę dla ewentualnych korekt. Listy słowne nie posiadały pełnego zrównoważenia fonetycznego, co było wynikiem istotnych braków w opracowaniach dotyczących procentowego rozkładu występowania poszczególnych głosek w języku polskim.

Przełomowa praca, która stanowiła podstawę zrównoważenia fonetycznego i zrównoważenia fonematycznego, została opublikowana w roku 1957 przez Marię Steffen. Dotyczyła częstości występowania głosek w języku polskim [12]. $\mathrm{Na}$ podstawie tego opracowania Wiktor Jassem i współpracownicy utworzyli listy zawierające wyrazy fonetycznie zrównoważone. Jednakże ze względu na to, że testy zawierały wyrazy o różnej liczbie sylab, okazały się mało przydatne do badań audiometrycznych [13-17].

Niezależnie od Steffen [12], Józef Taniewski, Ryszard Kugler i Zbigniew Wysocki z Kliniki Otolaryngologicznej w Szczecinie opracowali klasyfikację częstości występowania głosek w języku polskim [18]. Przeanalizowali 100000 głosek, które wchodziły w skład 20000 słów zaczerpniętych z ówczesnego piśmiennictwa polskiego. Rozróżnili 56 głosek występujących w języku polskim oraz obliczyli,

1. Określenie stopnia utraty słuchu w decybelach [dB HL] lub w procentach [\%]. 
Tabela 1. Chronologiczny wykaz testów słownych wykorzystywanych w audiometrii mowy w Polsce według dostępnej literatury

Table 1. Chronological list of speech tests used in speech audiometry in Poland, according to the available literature

\begin{tabular}{|c|c|c|}
\hline $\begin{array}{l}\text { Rok utworzenia } \\
\text { testu stownego }\end{array}$ & Rodzaj testu słownego & $\begin{array}{l}\text { Nazwiska autorów/miejsce } \\
\text { opracowania testów }\end{array}$ \\
\hline 1953 & Listy stów jednosylabowych & $\begin{array}{l}\text { A. Zakrzewski, W. Suwalski, } \\
\text { F. Antkowski, J. Suwalski }\end{array}$ \\
\hline 1957 & Listy wyrazów o różnej liczbie sylab & J. Jassem, R. Piela, M. Steffen \\
\hline 1961 & $\begin{array}{l}\text { Lista stów jednosylabowych i dwusylabowych bez zrównoważenia } \\
\text { fonetycznego) }\end{array}$ & J. Taniewski, R. Kugler, Z. Wysocki \\
\hline 1963 & $\begin{array}{l}\text { Test zdaniowy dla dorostych i dzieci, test liczbowy i test } \\
\text { logatomowy }\end{array}$ & S. Iwankiewicz, Siciński \\
\hline 1963 & Listy stów jednosylabowych dla dzieci & Z. Szmeja, A. Pruszewicz, K. Dukiewicz \\
\hline 1964 & Testy słowne dla dzieci w wieku przedszkolnym i szkolnym & R. Kugler \\
\hline lata 70. XX w. & $\begin{array}{l}\text { Badania słuchu szeptem u dzieci z uwzględnieniem wieku } \\
\text { rozwojowego badanych }\end{array}$ & $\begin{array}{l}\text { D. Borkowska-Gaerting, I. Urbańska, } \\
\text { B. Potyrała, t. Sobieszczańska- } \\
\text {-Radoszewska }\end{array}$ \\
\hline 1971 & Listy stów jednosylabowych i dwusylabowych & $\begin{array}{l}\text { A. Zakrzewski, A. Pruszewicz, } \\
\text { H. Kubzdela }\end{array}$ \\
\hline 1993 & Listy NLA-93 - listy wyrazów jednosylabowych i listy liczbowe & $\begin{array}{l}\text { A. Pruszewicz, G. Demenko, L. Richter, } \\
\text { T. Wika }\end{array}$ \\
\hline 1996 & $\begin{array}{l}\text { Testy słowne do badania percepcji mowy u dzieci z wszczepami } \\
\text { ślimakowymi z uwzględnieniem specyfiki języka polskiego } \\
\text { (na podstawie programu TAPS z ośrodka Cochlear z Bazylei) }\end{array}$ & $\begin{array}{l}\text { G. Demenko, L. Richter, } \\
\text { A. Pruszewicz, W. Szyfter, B. Woźnica }\end{array}$ \\
\hline 2004 & Polskie listy stów dwusylabowych & $\begin{array}{l}\text { R.W. Harris, W.S. Nielson, } \\
\text { D.L. McPherson, H. Skarżyński }\end{array}$ \\
\hline $2009-2015$ & $\begin{array}{l}\text { Polskie testy do badań zrozumiałości mowy dla dzieci, młodzieży } \\
\text { i dorostych }\end{array}$ & E. Ozimek \\
\hline 2011 & $\begin{array}{l}\text { Polski test słowny i liczbowy: spełnia wymagania polskiej normy } \\
\text { PN-EN ISO 8253-3: } 2005\end{array}$ & G. Demenko, A. Pruszewicz \\
\hline 2013 & $\begin{array}{l}\text { Test rozumienia zdań w szumie HINT (na podstawie protokółu } \\
\text { opracowanego w Department of Human Communication Sciences } \\
\text { and Devices, House Ear Institute (HEI) w Stanach Zjednoczonych) }\end{array}$ & M. Śliwińska-Kowalska \\
\hline
\end{tabular}

w jakiej procentowej zależności względem siebie występują poszczególne głoski. Na tej podstawie w roku 1961 utworzyli listy słów jednosylabowych i dwusylabowych. Do testów dwusylabowych autorzy wybrali 100 słów i podzielili je na dwie grupy A i B. Grupy te składały się z pięciu podgrup po 10 słów każda (jednakowa liczba słów łatwych i trudnych). Listy artykulacyjne posiadały zrównoważenie fonetyczne. Do testów jednosylabowych autorzy wybrali 200 słów, które zostały podzielone, podobnie jak w poprzedniej liście, na dwie grupy. Każda z grup zawierała pięć podgrup, w której znalazło się po 20 słów. Test z wyrazami dwusylabowymi służył jedynie do określania stopnia ubytku słuchu, natomiast test $\mathrm{z}$ wyrazami jednosylabowymi pozwalał określić zdolność rozróżniania słów.

W 1963 roku w Klinice Otolaryngologicznej we Wrocławiu Stanisław Iwankiewicz, bazując na opracowaniach Steffen [19], przygotował testy fonetycznie zrównoważone, obejmujące test zdaniowy dla dorosłych i dzieci, test liczbowy i test logatomowy [20-22]. W teście liczbowym zostały zawarte liczby od 1 do 100 . Utworzono z nich dziesięć list po 10 liczb. Siedem liczb występuje w tych testach po dwa razy - $21,24,36,48,66,71,73$. Warto podkreślić fakt, że pomimo braku zrównoważenia strukturalnego testy liczbowe stały się w Polsce popularnym narzędziem do oceny stopnia utraty słuchu. Jednak ze względu na to, że osoby z dużym niedosłuchem osiągały w teście liczbowym próg dyskryminacji mowy (100\% identyfikacji prezentowanych jednostek słownych) zaczęto opracowywać test zdaniowy, który miał zdecydowanie większy stopień trudności i większą wartość diagnostyczną. Test ten uwzględniał warunki zrównoważenia fonetycznego. Składał się z 5 list zawierających po 10 zdań - pytań lub poleceń. Do testowania list lingwistycznych dobrano dwie grupy po 50 osób z prawidłowym słuchem. W pierwszej grupie były dzieci w wieku 7 lat, w drugiej - dorośli o wykształceniu podstawowym, pracownicy fizyczni i rolnicy. Podczas ustalania krzywej artykulacyjnej przeprowadzono 100 badań w dwóch grupach z 50 uczestnikami z prawidłowym słuchem. W pierwszej grupie było 25 dzieci siedmioletnich, natomiast w drugiej 25 absolwentów średniej szkoły ogólnokształcącej. Dla określenia równoważności list przeprowadzono badania, zmieniając kolejność zdań, i okazało się, że wyniki nie odbiegały od siebie więcej niż $5 \mathrm{~dB}$ na progu rozumienia.

W tym samym roku (1963) Zygmunt Szmeja, Antoni Pruszewicz i Kazimierz Dukiewicz [23] z Kliniki 
Otolaryngologicznej Akademii Medycznej w Poznaniu i z Zakładu Fonograficznego Uniwersytetu Adama Mickiewicza w Poznaniu ułożyli 10 jednosylabowych list słownych, wykorzystując pracę Zakrzewskiego z 1953 roku [11] oraz Steffen z 1962 roku [19]. Listy te zostały wykorzystane do badań identyfikacji mowy oraz wyrazistości i rozróżniania głosek u 50000 dzieci szkolnych z różnych środowisk. Wskaźnik kontroli poziomu natężenia dźwięku mowy pozwalał na odtwarzanie list na jednakowym poziomie. W czasie badania listy słowne były odtwarzane w 20 jednousznych słuchawkach dla osób badanych oraz jednej słuchawce kontrolnej dla osoby prowadzącej badanie. Innowacją wobec innych list artykulacyjnych było to, że odstęp pomiędzy prezentowanymi słowami wynosił 10 sekund, tak aby dziecko miało czas na zanotowanie usłyszanego słowa. W celu uzyskania wzorcowej krzywej artykulacyjnej autorzy przebadali utworzonymi listami 1000 dzieci w klasach od trzeciej do siódmej szkoły podstawowej. Badane dzieci miały dodatkowo wykonane progowe badanie słuchu. Każda z 10 list była odsłuchiwana na wszystkich poziomach natężeń dźwięku podawanych jednostek słownych. Dzieci były badane w cichych pomieszczeniach w szkole (w klasach) oraz w wygłuszonym pomieszczeniu do badań audiometrycznych w klinice, zaadaptowanych tak, aby przypominały klasę. Testy te posiadały zrównoważenie strukturalne i fonetyczne, ale tylko wobec siebie. Autorzy nie uwzględnili podczas ich tworzenia frekwencyjności występowania słów w języku polskim.

Kolejne testy słowne dla dzieci w wieku przedszkolnym i szkolnym powstały w roku $1964 \mathrm{w}$ Klinice Otolaryngologicznej w Szczecinie [24]. Listy słowne ułożone przez Ryszarda Kuglera zawierały rzeczowniki łatwe i trudne w takim stosunku, w jakim występują w przeciętnej mowie. Podczas procesu tworzenia list słów jedno- i dwusylabowych autor brał pod uwagę wyniki badań Steffen [12,19], dotyczące częstości występowania poszczególnych głosek w języku polskim, oraz prace Taniewskiego i wsp. [18]. W tym celu obliczono częstość występowania rzeczowników jedno- i dwusylabowych, analizując teksty w mowie ciągłej. W tekście zawierającym 500000 słów było 635 rzeczowników jednosylabowych i 647 dwusylabowych. Częstość występowania tych wyrazów w tekście stanowiła podstawę do określenia stopnia ich trudności. Testy dla dzieci przedszkolnych utworzono wyłącznie $\mathrm{z}$ nazw istot i rzeczy, które są dobrze znane małym dzieciom. Dodatkowo były zilustrowane obrazkami.

W latach 70. XX wieku w Instytucie Matki i Dziecka opracowano i dokonano standaryzacji przesiewowych metod badania słuchu szeptem u dzieci, uwzględniając wiek rozwojowy badanych [25-27]. Badania w grupie najmłodszych dzieci (8-12 miesięcy) opierały się na teście Ewinga. Autorzy testów wybrali przedmioty i instrumenty muzyczne, które generowały dźwięki o określonym poziomie i widmie dźwięku - od 40 do 100 dB SPL. Badania w grupie starszych dzieci, w wieku od 3 do 5 lat, oparte zostały na zasadzie - „pokaż to, co słyszysz”. Dziecko miało za zadanie wskazać ilustrację odpowiadającą słowu wypowiadanemu szeptem z odległości 3 metrów. W badaniu trzeciej grupy wiekowej (6-12 lat) wykorzystywano zasadę - „powtórz to, co słyszysz”. Dziecko powtarzało słowa wypowiadane do niego szeptem $z$ odległości 5 metrów. W obu grupach wiekowych badano każde z uszu osobno, maskując ucho niebadane ${ }^{2}$.

W 1971 roku Aleksander Zakrzewski, Antoni Pruszewicz i Henryk Kubzdela [28] z Kliniki Otolaryngologicznej Akademii Medycznej i Pracowni Fonetyki Akustycznej PAN w Poznaniu zmodyfikowali listy artykulacyjne Zakrzewskiego z 1953 roku $^{3}$, opierając się na pracach Steffen z 1962 roku [19], dotyczących zrównoważenia strukturalnego wyrazów jedno- i dwusylabowych języka polskiego, obliczonych na materiale 32000 wyrazów. Zakrzewski i wsp., znając częstość występowania wyrazów jedno- i dwusylabowych, mogli ułożyć listy w taki sposób, aby struktura list słownych była taka sama jak w języku polskim. Okazało się to ważnym krokiem w rozwoju audiometrycznych testów słownych w Polsce. Każda z 10 list składa się z 14 wyrazów jednosylabowych oraz 15 dwusylabowych rozmieszczonych w stosunku do siebie w ten sam sposób na poszczególnych listach, $\mathrm{z}$ uwzględnieniem założenia zrównoważenia strukturalnego. Wyrazy zawarte w testach słownych były powszechnie znane i pozbawione zabarwienia emocjonalnego. Przyjęto zatem, iż spełniają założenia subiektywnego zrównoważenia semantycznego. Autorzy potwierdzili w procesie wstępnych badań także to, że utworzone listy słowne posiadają zrównoważenie dynamiczne. Testy te obowiązywały do lat 90 . XX wieku, a w niektórych klinikach stosowane są do dzisiaj.

Testy słowne znane pod nazwą NLA-93 powstały w roku 1993 dzięki rozwojowi techniki, postępowi prac z zakresu akustyki i percepcji dźwięków, nowym opracowaniom klasyfikacji akustycznej polskich fonemów oraz ukazaniu się słowników frekwencyjnych dla języka polskiego [29]. Utworzyli je Antoni Pruszewicz, Grażyna Demenko, Lutosława Richter i Teresa Wika w Klinice Foniatrii i Audiologii AM w Poznaniu i Zakładzie Fonetyki Akustycznej Instytutu Podstawowych Problemów Techniki PAN w Poznaniu. Autorzy wybrali z 10355 haseł słownika frekwencyjnego materiał słowny zawierający 562 rzeczowniki jednosylabowe, które były najczęściej używane $\mathrm{w}$ języku polskim $\mathrm{w}$ tamtym okresie. W pracach dotyczących klasyfikacji akustycznej wykorzystano klasyfikację polskich fonemów Wiktora Jassema [14], prace Piotry Łobacz [30-32], które były poświęcone percepcji fonemów języka polskiego, oraz pracę Jeffreya L. Danhauera [33] opisującą zagadnienia percepcji mowy u osób z niedosłuchem. Z powyższych prac autorzy wyselekcjonowali najistotniejszą cechę w percepcji mowy - sybilantność, czyli istnienie lub brak silnego szumu. Zgodnie $\mathrm{z}$ tą zasadą przyjęli podział fonemów na trzy grupy - niskie, wysokie i zwarte. Dokonano transkrypcji fonematycznej oraz klasyfikacji materiału słownego według przyjętych zasad. Następnie określono kolejność występowania samogłosek i spółgłosek. Uwzględniając określone struktury mowy, utworzono w pełni zrównoważone testy słowne, składające

\footnotetext{
2. W audiometrii wykorzystuje się tzw. maskowanie jednoczesne, czyli takie, w którym sygnał prezentowany jest w tym samym czasie co dźwięk maskujący, np. w celu wyeliminowania przesłuchu międzyusznego.

3. Modyfikacja testu słownego Zakrzewskiego z 1953 roku miała na celu utworzenie list, które zrównoważone byłyby nie tylko pod względem fonetycznym, lecz także strukturalnie.
} 
się z 10 list artykulacyjnych, z których każda zawierała 24 wyrazy. Testy te używane są w codziennej diagnostyce audiologiczno-protetycznej do dziś.

Kolejnym wartym przypomnienia zestawem testów słownych są listy do badania percepcji mowy u dzieci z wszczepami ślimakowymi z uwzględnieniem specyfiki języka polskiego, powstałe w roku 1996 w Zakładzie Fonetyki Akustycznej Instytutu Podstawowych Problemów Techniki PAN w Poznaniu przy współpracy z Kliniką Foniatrii i Audiologii oraz z Kliniką Otolaryngologii AM w Poznaniu na podstawie programu TAPS (ang. Test of Auditory Perception of Speech for Children) $\mathrm{z}$ ośrodka Cochlear z Bazylei [34]. Zgodnie z zaleceniem Cochlear Centrum $\mathrm{w}$ Bazylei autorzy ujęli materiał lingwistyczny w pięć kategorii: wykrywanie dźwięków mowy, percepcja wzorców rytmicznych mowy, identyfikacja mowy (w tym percepcja podstawowych struktur fonetyczno-akustycznych języka polskiego, percepcja wzorców rytmicznych oraz identyfikacja wyrazów, identyfikacja samogłosek oraz głosek w wyrazach), identyfikacja zdań i rozpoznawanie mowy w zestawach. Materiał językowy wykorzystany w teście został przygotowany tak, aby uwzględniał cechy fonetyczno-akustyczne i gramatyczne języka polskiego. Ograniczeniem tego testu jest to, że nie ma on zastosowania w badaniu kwalifikacyjnym do wszczepienia implantu ślimakowego u dzieci 2-3-letnich, które nie rozwinęły mowy.

W ramach współpracy Instytutu Fizjologii i Patologii Słuchu w Warszawie oraz Brigham Young University w Provo w USA w 2004 roku zostały opracowane zrównoważone psychometrycznie polskie listy słów dwusylabowych [35]. Materiał słowny stanowiło 70 słów dwusylabowych powszechnie używanych $\mathrm{w}$ języku polskim $\mathrm{z}$ akcentem na pierwszą sylabę. Listy były czytane przez lektorów (mężczyznę i kobietę) pochodzących z centralnej Polski (wykluczenie elementu gwary w wymowie). W grupie 26 osób ze słuchem prawidłowym wykreślono dla każdego z 70 słów krzywą psychometrycznąa , oddzielnie dla kolejnych 15 poziomów natężenia dźwięku od -10 do $18 \mathrm{~dB}$ HL (co $2 \mathrm{~dB}$ ). Ostatecznie wybrano 25 słów dwusylabowych o najbardziej stromym nachyleniu krzywej psychometrycznej. Dla uzyskania efektu jednorodności listy słownej dokonano cyfrowej regulacji natężenia każdego ze słów, tak aby próg zrozumiałości każdego z nich wynosił 2,37 dB HL. Końcowym efektem była lista słów dwusylabowych jednorodnych pod względem wartości progów słyszenia, a także nachylenia krzywej psychometrycznej.

W roku 2009 rozpoczęto prace nad polskimi testami zdaniowymi. Zestaw testów opracowanych pod kierownictwem Edwarda Ozimka [36-39] umożliwiał diagnostykę dyskryminacji mowy u osób ze słuchem prawidłowym, jak również u osób korzystających z urządzeń wspomagających słyszenie, takich jak aparat słuchowy czy implant ślimakowy. Testy do oceny zrozumiałości mowy dostępne są jako aplikacje komputerowe. Obejmują one testy przeznaczone dla młodzieży i dorosłych - Polski Test Zdaniowy (PTZ), Polski Test Zdaniowy typu Matrix (PTZ-M) oraz Polski Test Zdaniowy Zrozumiałości Mowy Przyspieszonej typu Matrix (PTZMP-M), a także testy przeznaczone dla dzieci - Polski Pediatryczny Test Zdaniowy typu
Matrix (PPTZ-M). Dodatkowo utworzono Polski Test Trypletów Cyfrowych (PTTC), który wykorzystuje sekwencję cyfr i spełnia rolę testu przesiewowego. Najczęściej wykorzystywany w diagnostyce audiologicznej jest PTZ-M.

Kolejnym testem lingwistycznym opisywanym w literaturze jest Polski Test Słowny i Liczbowy opracowany w roku 2011 przez Grażynę Demenko i Antoniego Pruszewicza w Zakładzie Fonetyki Instytutu Językoznawstwa Uniwersytetu im. A. Mickiewicza i w Katedrze i Klinice Foniatrii i Audiologii Uniwersytetu Medycznego im. K. Marcinkowskiego w Poznaniu [40]. Test liczbowy utworzony zostal z 10 list, a w każdej z nich zawarto po 10 liczb. Test słowny zawiera 10 list składających się z 20 słów jednosylabowych każda i jest modyfikacją testu NLA-93 Pruszewicza (1993). Różnice pomiędzy testami zobrazowano w tabeli 2.

W roku 2013 w Klinice Audiologii i Foniatrii Instytutu Medycyny Pracy w Łodzi Mariola Śliwińska-Kowalska wraz z zespołem, opierając się na protokole opracowanym w Department of Human Communication Sciences and Devices, House Ear Institute (HEI) w Stanach Zjednoczonych, utworzyła listy zdaniowe składające się na test rozumienia zdań w szumie (ang. Hearing in Noise Test, HINT) dla języka polskiego $[41,42]$. Autorzy podkreślają fakt, że do oceny sprawności narządu słuchu w odniesieniu do komunikacji międzyludzkiej powinna być wykorzystywana mowa w szumie. Proces opracowania testu HINT obejmował przygotowanie pisemnej listy zdań oraz ich nagranie. Kolejnym etapem było wyznaczenie funkcji PI (ang. Perfomance - Intensity Function) oraz zrównoważenie zdań pod względem zrozumiałości. Efektem końcowym było utworzenie 20 list zdaniowych. Polskie testy HINT znajdują zastosowanie $\mathrm{w}$ określaniu przydatności do pracy, w której wymagany jest dobry słuch.

Omawiając temat testów słownych wykorzystywanych i dostepnych w Polsce, warto wspomnieć także o testach mowy utrudnionej. Badania nad wyrazistością i rozróżnialnością głosek były jednymi z pierwszych prób oceny ośrodkowych procesów przetwarzania sygnałów mowy [16]. Pierwsze w świecie testy do oceny ośrodkowych zaburzeń procesów słuchowych były tworzone w latach 50 . XX wieku $[43,44]$. Testy słowne wykorzystywane do badań ośrodkowych zaburzeń przetwarzania słuchowego powinny spełniać zasady zrównoważenia semantycznego, a co najważniejsze zrównoważenia fonetycznego. Testy mowy utrudnionej dla języka polskiego zostały opracowane w Katedrze i Klinice Foniatrii i Audiologii Uniwersytetu Medycznego im. Karola Marcinkowskiego w Poznaniu i Zakładzie Fonetyki Instytutu Językoznawstwa Uniwersytetu im. Adama Mickiewicza w Poznaniu [45-48]. Są to między innymi testy oceniajace zaburzenia sekwencji czasowych w procesie słyszenia oraz testy jednouszne, które miały na celu ocenę zdolności odkodowania zniekształconego materiału słownego w korowych ośrodkach słuchowych. W opracowanych testach wykorzystano listy wyrazów jednosylabowych NLA-93 [29]. W teście mowy filtrowanej zastosowano filtrację górno- i dolnoprzepustową przy poziomie $55 \mathrm{~dB}$ HL, natomiast w teście słyszenia mowy w hałasie szum o natężeniu o $10 \mathrm{~dB}$ mniejszym od prezentowanego bodźca (stosunek sygnału do szumu $-\mathrm{SNR}=10 \mathrm{~dB}$ ).

\footnotetext{
4. Krzywa psychometryczna obrazuje zależność pomiędzy procentem spostrzegania bodźca a poziomem jego cechy.
} 
Tabela 2. Zestawienie zmian wprowadzonych w teście słownym Demenko (2011) względem list NLA-93 Pruszewicza (1993)

Table 2. Summary of changes in the Demenko's speech test (2011) against the Pruszewicz's speech test NLA-93 (1993)

\begin{tabular}{|c|c|c|}
\hline $\begin{array}{c}\text { Test słowny NLA-93 Pruszewicza } \\
\text { (1993) }\end{array}$ & $\begin{array}{l}\text { Test słowny Demenko } \\
\text { (2011) }\end{array}$ & $\begin{array}{c}\text { Dodatkowa zmiana w listach Demenko } \\
\text { względem NLA-93 }\end{array}$ \\
\hline Lista I & Lista V & 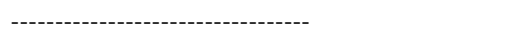 \\
\hline Lista II & Lista IV & słowo lód zastąpiono słowem lud \\
\hline Lista III & Lista III & słowo gnój zastąpiono słowem kłus \\
\hline Lista IV & Lista II & 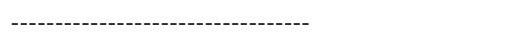 \\
\hline Lista V & Lista I & słowo byt zastąpiono słowem pit \\
\hline Lista VI & Lista X & $\begin{array}{l}\text { słowo bieg zastąpiono słowem grad } \\
\text { stowo lud zastąpiono stowem lód }\end{array}$ \\
\hline Lista VII & Lista VIII & --------------------------------- \\
\hline Lista VIII & Lista IX & $\begin{array}{l}\text { słowo płeć zastąpiono słowem krzyż } \\
\text { słowo dzicz zastąpiono słowem cześć }\end{array}$ \\
\hline Lista IX & Lista VII & ------------------------------- \\
\hline Lista X & Lista VI & 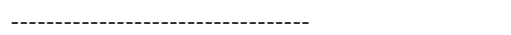 \\
\hline
\end{tabular}

Kolejnym testem był test mowy zagęszczonej, w którym przyspieszono wypowiadany materiał słowny o $25 \%$ w stosunku do normy. Utworzono również testy dychotyczne - obuuszne, na które składały się test liczbowy oraz słowny. Podczas ustalania zawartości list wykorzystywano pary minimalne, czyli dwa słowa bądź frazy z języka polskiego różniące się jednym fonemem, mające inne znaczenie np. paczka, taczka. Dodatkowo dostosowano test mowy przerzucanej ${ }^{5}$ dla języka polskiego.

\section{Podsumowanie}

Otolog Fryderyk Bezold ${ }^{6}$ żyjący na przełomie XIX i XX wieku powiedział, że mowa „(...) zawiera tak pełne zestawienie wszystkich możliwych dźwięków, że musielibyśmy mowę wynaleźć i używać jej do badań, gdybyśmy jej nie znali” [49].

Celem pracy było przedstawienie opisanych w dostępnej literaturze przedmiotu testów słownych dla języka polskiego. Zobrazowano proces tworzenia i modyfikacji list lingwistycznych w różnych ośrodkach badawczych, począwszy od 1953 roku do czasów współczesnych.
Testy słowne stosowane w audiometrii mowy pełnią ważną rolę w diagnostyce zaburzeń słuchu. Ze względu na swoją różnorodność pozwalają na wykrycie nieprawidłowości występujących na poszczególnych poziomach drogi słuchowej. Dzięki nowym technologiom w dziedzinie akustyki i percepcji dźwięków możliwe jest tworzenie coraz nowszych i bardziej dokładnych opracowań list słownych, między innymi poprzez odpowiedni dobór materiału słownego i zastosowanie właściwych zabiegów językoznawczych. Należy jednak podkreślić, że na wiarygodność wyniku wpływają nie tylko odpowiednio przygotowane listy słowne, lecz także czynnik ludzki, jakim jest potrzeba skupienia się czy wykorzystania umiejętności odbioru, analizy i syntezy słuchowej otrzymywanych sygnałów. W procesie diagnostyki zaburzeń słuchu $\mathrm{z}$ wykorzystaniem audiometrii mowy istotną rolę odgrywa również prawidłowa interpretacja wyników związana z porównaniem otrzymywanych zapisów z krzywymi wzorcowymi opracowywanymi dla każdego testu słownego (np. jednosylabowego, dwusylabowego, zdaniowego, liczbowego) osobno.

Publikacja powstała $w$ zwiazku $z$ realizacja projektu pn. „Zintegrowany system narzędzi do diagnostyki i telerehabilitacji schorzeń narząów zmystów (słuchu, wzroku, mowy, równowagi, smaku, powonienia)" INNOSENSE, wspólfinansowanego przez Narodowe Centrum Badań i Rozwoju w ramach Programu STRATEGMED.

\footnotetext{
5. Test mowy przerzucanej wg Calearo polega na podawaniu podzielonych na sylaby zdań na przemian do jednego i drugiego ucha. Zaproponowano 5 zdań. Najkrótsze pierwsze zdanie składa się z trzech sylab, natomiast ostatnie z dziesięciu. Zdania zawierają wyrazy powszechnie znane. Dwa zdania z pięciu charakteryzują się intonacją wyraźnie rosnącą.

6. Współtwórca zestawu stroików widełkowych (stroiki Bezolda) i metody badania słuchu przy ich wykorzystaniu. Współpracował ze szkołami dla niesłyszących, gdzie u dzieci z resztkami słuchowymi stosował ćwiczenia słuchowe. Uważał, że polepszenie słyszenia leży w sferze psychicznej. Skupiał się na uczeniu niesłyszących dzieci jednostek znaczeniowych, a nie na rozróżnianiu głosek.
} 


\section{Piśmiennictwo:}

1. Dukiewicz L, Sawicka I. Fonetyka i fonologia. Gramatyka współczesnego języka polskiego t. 3. Kraków: Wydawnictwo Instytutu Języka Polskiego PAN; 1995.

2. Obrębowski A. (red). Wybrane zagadnienia $\mathrm{z}$ audiometrii mowy. Poznań: Wydawnictwo Naukowe Uniwersytetu Medycznego im. Karola Marcinkowskiego; 2011.

3. Demenko G, Pruszewicz A, Wojnowski W. Audiometria mowy. Za: Pruszewicz A, Obrębowski A, red. Audiologia kliniczna zarys. Poznań: Wydawnictwo Naukowe Uniwersytetu Medycznego im. Karola Marcinkowskiego; 2010, s. 226-61.

4. Surmanowicz-Demenko G. Podstawy lingwistyczne i fonetyczne testów słownych. W: Obrębowski A, red. Wybrane zagadnienia $\mathrm{z}$ audiometrii mowy. Poznań: Wydawnictwo Naukowe Uniwersytetu Medycznego im. Karola Marcinkowskiego; 2011, s. $69-84$.

5. Hojan E. (red). Protetyka słuchu. Poznań: Wydawnictwo Naukowe UAM; 2014.

6. Sekula A, Świdziński P. Audiometria mowy w protezowaniu i rehabilitacji słuchu. W: Obrębowski A, red. Wybrane zagadnienia $\mathrm{z}$ audiometrii mowy. Poznań: Wydawnictwo Naukowe Uniwersytetu Medycznego im. Karola Marcinkowskiego; 2011, s. $117-32$.

7. Pruszewicz A, Wiskirska-Woźnica B. Przydatność audiometrii mowy w diagnostyce zaburzeń słuchu. W: Obrębowski A, red. Wybrane zagadnienia $\mathrm{z}$ audiometrii mowy. Poznań: Wydawnictwo Naukowe Uniwersytetu Medycznego im. Karola Marcinkowskiego; 2011, s. 110-16.

8. Chermak G, Musiek F. Central Auditory Processing Disorders. New Perspectives. Singular Publishing Group, San Diego; 1997.

9. Fletcher $\mathrm{H}, \mathrm{Galt} \mathrm{RH}$. The perception of speech and its relation totelephony. J Acoust Soc Am, 1950; 22: 89.

10. Wojnowski W. Rozwój audiometrii mowy. W: Obrębowski A, red. Wybrane zagadnienia $z$ audiometrii mowy. Poznań: Wydawnictwo Naukowe Uniwersytetu Medycznego im. Karola Marcinkowskiego, 2011; s. 52-55.

11. Zakrzewski A, Suwalski W, Antkowski F, Suwalski T. Próba ustalenia list „fonetycznie zrównoważonych” dla badania słuchu przy pomocy prób artykulacyjnych. Otolaryng Pol, 1953; 7(2): 93.

12. Steffen M. Częstość występowania głosek polskich. Biul Pol Tow Językoznaw, 1957; 16: 145.

13. Jassem W. Mowa a nauka o łączności. Warszawa: PWN; 1974.

14. Jassem W. Podstawy fonetyki akustycznej. Warszawa: Państwowe Wydawnictwo Naukowe; 1973.

15. Jassem W. Acoustic - phonetic variability of polish vowels. Archieves of Acoustics, 1992; 17(2): 217-33.

16. Jassem W. Polskie listy wyrazowe ze zrównoważeniem fonetycznym i częstościowym. Technologia Mowy i Języka. Poznań: Polskie Towarzystwo Fonetyczne; 1971.

17. Piela R, Dukiewicz L. Szczegółowe badania wyrazistości i rozróżnialności głosek polskich w różnych warunkach przenoszenia. Biul Wojsk Akad Tech, 1962; 11(4): 416.

18. Taniewski J, Kugler R, Wysocki Z. Audiometria słowna mową polską. Otolaryng Pol, 1961; 15: 131.

19. Steffen M. Polskie testy do badań nad wyrazistością i zrozumiałością mowy. Przegl Telekom, 1962; 3: 82.

20. Iwankiewicz S. Audiometria mowy. Otolaryng Pol, 1961; 15(1): 277.
21. Iwankiewicz S. Audiometria mowy wieku dziecięcego. Otolaryng Pol, 1963; 17, 4.

22. Iwankiewicz S. Zastosowanie prób artykulacyjnych w orzecznictwie (propozycja ujednolicenia metodyki). Otolaryng Pol, 1961; 15: 307.

23. Szmeja Z, Pruszewicz A, Dukiewicz K. Metoda masowego wstępnego badania słuchu u dzieci szkolnych audiometrią słowną. Otolaryng Pol, 1963; 17(4): 367.

24. Kugler R. Audiometria słowna u dzieci. Otolaryng Pol, 1964; 18(2).

25. Borkowska-Gaertig D, Potyrała B. Testy słowne do powszechnego stosowania w badaniach słuchu u dzieci szkolnych. Pediatria Polska, 1968; 43.

26. Borkowska-Gaertig D, Urbańska I. Testy słuchowe dla dzieci przedszkolnych do użytku pediatrów. Pediatria Polaka, 1969; 44: 11 .

27. Furman A. Audiometria dziecięca. W: Hojan E. (red) Protetyka słuchu. Poznań: Wydawnictwo Naukowe UAM; 2014.

28. Zakrzewski A, Pruszewicz A, Kubzdela H. Nowe listy artykulacyjne zrównoważone fonematycznie i strukturalnie. Otolaryng Pol, 1971; 25(3): 297

29. Pruszewicz A, Demenko G, Richter L, Wika T. Nowe listy artykulacyjne do badań audiometrycznych (cz. I). Otolaryng Pol, 1994; 48 (1): 50-62.

30. Łobacz P. Psychometric classification of phones - Some methodological consideratons. Lingua Posnaniensis, 1991; 22-23.

31. Łobacz P. Polska fonologia dziecięca; studia fonetyczno-akustyczne. Warszawa: Energia; 1996.

32. Łobacz P. O percepcji klasyfikacji raz jeszcze. Eufonia i Logos. Poznań: Wydawnictwa Uniwersytetu Adama Mickiewicza; 1995.

33. Danhauer JL, Lewarre RM. Dissimilarity rations of English conconants by normally-hearig and hearing-impaired individuals. J Speech Hear Res, 1979; 22(2): 236.

34. Demenko G, Rychter L, Pruszewicz A. Testy do badania słuchowej percepcji mowy (TBSPM) dla dzieci z implantem ślimakowym. Otolaryngol Pol, 1996; 50: 628.

35. Harris RW, Nielson WS, McPherson DL, Skarżyński H. Psychometryczne zrównoważone dwusylabowe polskie listy słowne. Audiofonol. 2004; 26: 1-13.

36. Ozimek E, Warzybok A, Sęk A, Wicher A. Polish sentence tests for measuring intelligibility of speech in interfering noise. Int J Audiol, 2009; 48(7): 433-43.

37. Ozimek E, Warzybok A, Kutzner D. Polish sentence matrix tests for speech intelligibility measurement in noise. Int J Audiol, 2010; 49(6): 444-54.

38. Polskie testy do badań zrozumiałości mowy - broszura. Poznań: Instytut Akustyki, Uniwersytet im. Adama Mickiewicza; 2011.

39. Ozimek E, Kutzner D, Sęk A, Wicher W. Nowe testy do pomiarów zrozumiałości mowy w szumie dla języka polskiego: test zdaniowy oraz test trypletów cyfrowych, Biuletyn PSPS, 2008; 29: 16.

40. Demenko G, Pruszewicz A. Dokumentacja techniczna. Polski test liczbowy i słowny do badania słuchu oraz testy do treningu słuchowego. Future Voice System. Poznań; 2011.

41. Śliwińska-Kowalska M, Kotyło P, Soli SD. Opracowanie list zdaniowych testu rozumienia zdań w szumie dla języka polskiego. Otorynolaryngol, 2013, 12(4): 176-82.

42. Soli SD. Some thoughts on communication handicap and hearing impairment. Int J Audiology, 2008; 47(6): 285-86. 
43. Bocca E, Calearo C. Central hearing processes. W: Jerger J, red. Modern developments in audiology. New York: Academic Press, 1963; 337-70.

44. Mendel LL, Danhauer J. Speech perception assessment. San Diego: Singular Publishing Group; 1996.

45. Wojnowski W, Obrębowski A, Pruszewicz A, Demenko G, Wiskirska-Woźnica B, Wika T, Komar D. Testy utrudnione w audiometrii mowy dla języka polskiego. Część I: Przygotowanie materiału testowego. Otolaryngol Pol, 2006; 60(3): 385-90.

46. Wojnowski W, Obrębowski A, Pruszewicz A, Demenko G, Wiskirska-Woźnica B, Świdziński P, Maciejewska B. Przydatność testów utrudnionych w diagnostyce dysleksji u dzieci. Otorynolaryngol, 2008; 7(2): 97-100.
47. Wojnowski W, Obrębowski A, Pruszewicz A, Demenko G, Wiskirska-Woźnica B, Wika T, Komar D. Testy utrudnione w audiometrii mowy dla języka polskiego. Część II: Badania osób z prawidłowym słuchem w różnych grupach wiekowych. Otolaryngol Pol, 2006; 60(4): 559-64.

48. Demenko G, Obrębowski A, Pruszewicz A, Wojnowski W, Wika T, Wiskirska-Woźnica B. Polish dychotomic tests for audiometry. Arch Wcoust, 2003; 28(3): 251.

49. Eckert U. Wychowanie słuchowe w przebiegu historycznym. Audiofonol, 2004; 25: 61-63. 